Boletín de la Sociedad Geológica Mexicana

VOLUMEN 60, NÚM. 1, 2008, P. 101-110

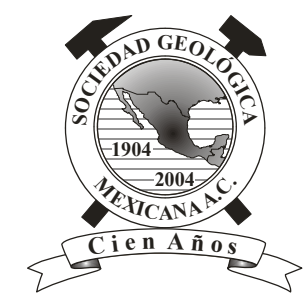

\title{
New records for Crustacea from the Arida Formation (Lower Cretaceous, Barremian) of Japan
}

\author{
Hiroaki Karasawa ${ }^{1, *}$, Masaaki Ohara ${ }^{2}$, and Hisayoshi Kato ${ }^{3}$ \\ ${ }^{1}$ Mizunami Fossil Museum, Yamanouchi, Akeyo, Mizunami, Gifu 509-6132, Japan. \\ ${ }^{2}$ Wakayama Prefectural Museum of Natural History, Funao, Kainan, Wakayama 642-0001, Japan. \\ ${ }^{3}$ Natural History Museum and Institute, Chiba, 955-2, Aoba-cho, Chiba 260-8682, Japan. \\ *GHA06103@nifty.com
}

\begin{abstract}
Four new species of decapods and one new species of isopod are described from the Barremian (Lower Cretaceous) Arida Formation in Wakayama Prefecture, Japan. Xanthosia sakoi new species (Brachyura, Etyidae) and Palaega yamadai new species (Isopoda, Cirolanidae) represents the first record of each genus from the North Pacific realm. Xanthosia sakoi is the oldest member of this genus. Eryma nippon new species (Astacidea, Erymidae) is the first Cretaceous record for the genus Eryma from the North Pacific realm. Hoploparia natsumiae new species (Astacidea, Nephropidae) comprises the second record of this genus from the Barremian of Japan. Eomunidopsis kinokunica new species (Anomala, Galatheidae) represents the oldest record from the North Pacific realm. The systematic position of the family Etyidae is discussed and the Etyidae is elevated to full superfamily status.
\end{abstract}

Key words: Cretaceous, Crustacea, Decapoda, Isopoda, Etyidae, Japan.

\section{Resumen}

Cuatro especies nuevas de decápodos y una especie nueva de isópodo, son descritas para el Barremiano (Cretácico Inferior) de la Formación Arida en la Prefectura de Wakayama, Japón. Xanthosia sakoi especie nueva (Brachyura, Etyidae) y Palaega yamadai especie nueva (Isopoda, Cirolanidae), representan el primer registro de cada género para la región del Pacifico Norte. Xanthosia sakoi es el miembro más antiguo de éste género. Eryma nippon especie nueva (Astacidea, Erymidae), es el primer registro del Cretácico para el género Eryma en la región del Pacifico Norte. Hoploparia natsumiae especie nueva (Astacidea, Nephropidae), representa el segundo registro para éste género en el Barremiano de Japón. Eomunidopsis kinokunica especie nueva (Anomala, Galatheidae), representa el registro más antiguo para la región del Pacifico Norte. Se discute la posición sistemática de la familia Etyidae, y su estatus es elevado al de superfamilia.

Palabras clave: Cretácico, Crustacea, Decapoda, Isopoda, Etyidae, Japón. 


\section{Introduction}

The Barremian (Lower Cretaceous) decapod fossils have been poorly recorded from Japan. Callianassa s. 1. sakakuraorum Karasawa, 2000, and Glyphea yoshiakii Kato and Karasawa, 2006, have been known from the Arida Formation (Karasawa, 2000; Kato and Karasawa, 2006; Karasawa et al., 2006). Glyphea sp., Hoploparia kamimurai Kato and Karasawa, 2006, Callianassa s. 1. sp., and Nipponopon hasegawai Karasawa et al, 2006, have been recorded from the Barremian of the Sanchu region (Kato et al., 2006; Kato and Karasawa, 2006; Karasawa et al., 2006).

The collections of the Wakayama Prefectural Museum of Natural History contain specimens of crustaceans from the Barremian Arida Formation of Wakayama Prefecture, Japan. During the systematic survey of these crustaceans, the authors found a single species of isopod and six species of decapods, including previously known Callianassa s. 1. sakakuraorum and Glyphea yoshiakii. The purpose of this paper is to describe five additional new crustacean species, one isopod, two astacideans, one anomalan, and one brachyuran, from the Arida Formation.

The described specimens are deposited in the Wakayama Prefectural Museum of Natural History (WMNH-Ge).

\section{Localities and geological setting}

The Arida Formation is distributed in the Yuasaarea, Wakayama Prefecture, southwest Japan. This formation conformably overlies the Yuasa Formation and is unconformably overlain by the Nishihiro Formation (Obata and Ogawa, 1976). The Arida Formation consists of gravelly sandstone, sandstone, and mudstone, which contains numerous shallow-marine molluscs (Obata and Ogawa, 1976; Matsukawa and Obata, 1993; Komatsu, 1999). Obata and Ogawa (1976) and Matsukawa and Obata (1993) indicated that the geologic age of the Arida Formation is Barremian, based upon the occurrence of Crioceratites (Paracrioceras) asiaticum (Matsumoto, 1947) and Shastcrioceras nipponicum Matsumoto, 1947.

The crustaceans described herein were collected from the following localities (Figure 1):

Loc. 01. Cliff (now lost) of Suhara, Yuasa-cho, Wakayama Prefecture (34 ${ }^{\circ} 34.4^{\prime \prime} \mathrm{N}$; $\left.135^{\circ} 10^{\prime} 24.8^{\prime \prime} \mathrm{E}\right)$; Sandy mudstone of the Arida Formation.

Loc. 02. Cliff, northeast of loc. 1, Suhara, Yuasa-cho, Wakayama Prefecture (34²'35.6" N; 135 10'29.4" E); Sandy mudstone of the Arida Formation. Karasawa (2000) described Callianassa s.l. sakakuraorum Karasawa, 2000, and Hoploparia sp. from the same locality. Subsequently, Kato and Karasawa (2006) redescribed Hoploparia sp. as Glyphea yoshiakii Kato and Karasawa, 2006.

Loc. 03. Cliff (present lost), east of loc. 2, Suhara, Yuasacho, Wakayama Prefecture $\left(34^{\circ} 2^{\prime} 38.2^{\prime \prime} \mathrm{N} ; 135^{\circ} 11^{\prime} 20.8^{\prime \prime} \mathrm{E}\right)$;

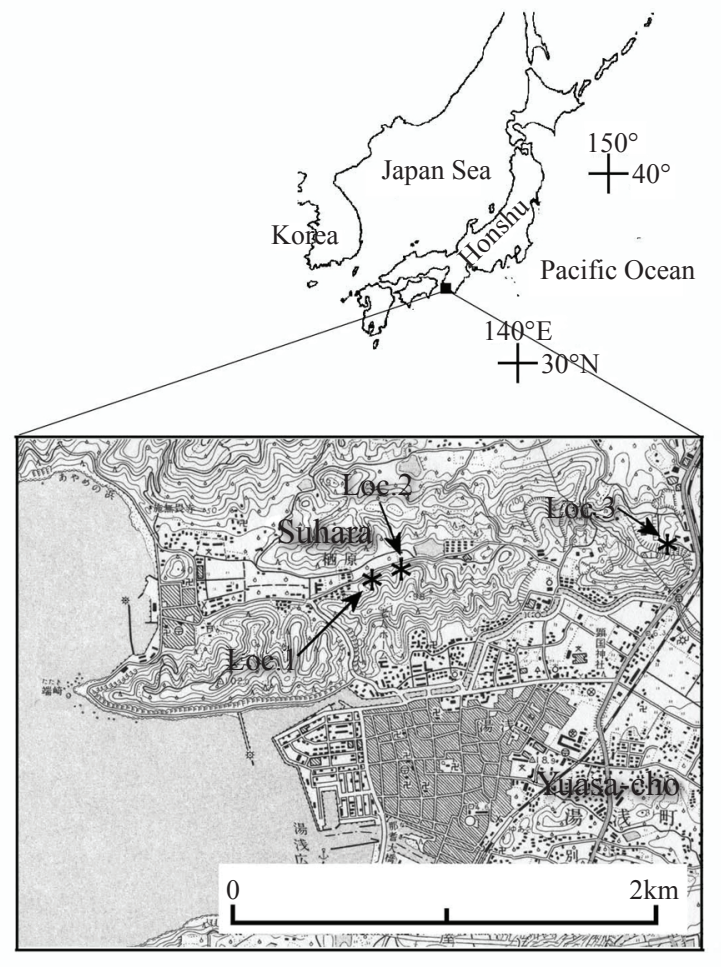

Figure 1. Map showing fossil-bearing localities (topographical map of "Yuasa", scale 1:25,000, published by Geographical Survey Institute of Japan).

Sandy mudstone of the Arida Formation.

\section{Systematics}

Order Decapoda Latreille, 1802

Suborder Reptantia Boas, 1880

Infraorder Astacidea Latreille, 1802

Superfamily Erymoidea Van Straelen, 1924

Family Erymidae Van Straelen, 1924

\section{Genus Eryma von Meyer, 1840}

Type species. Macrourites modestiformis von Schlotheim, 1822, by original designation.

\section{Eryma nippon new species}

Figures 2.6-2.9

Diagnosis. Moderate-sized Eryma. Rostrum short with rimmed lateral margins. Gastro-orbital groove weakly developed. Cervical groove deep, sinuous, extending ventrally to join deep antennal groove. Prominence omega and chi well defined. Hepatic groove deep, joining cervical and branchiocardiac grooves. Postcervical groove deep, but 


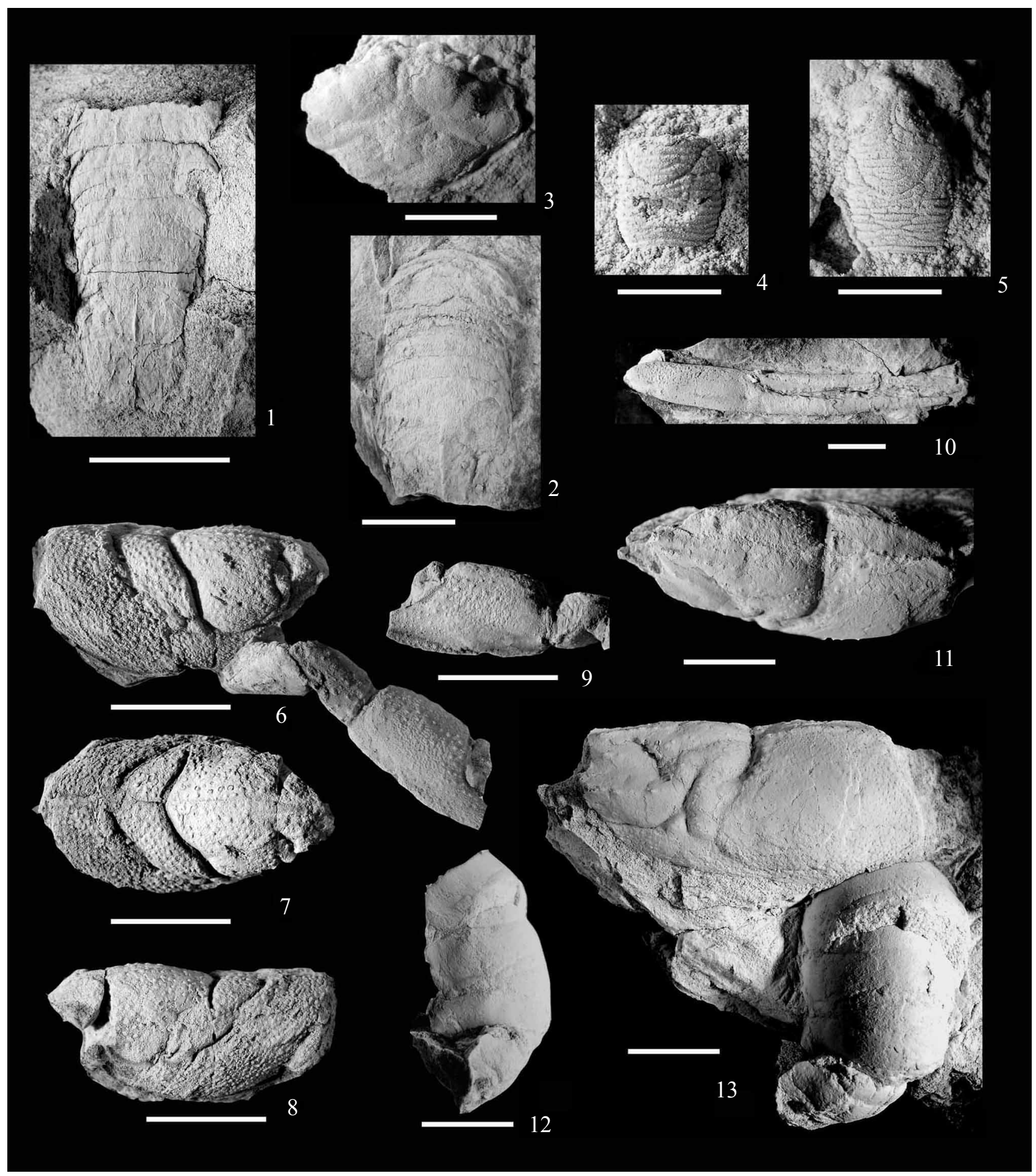

Figure 2. 1, 2: Palaega yamadai new species. 1: WMNH-Ge-1140320049 (holotype), pereonites, pleonites, and pleotelson, dorsal view. 2: WMNHGe-1140320050 (paratype), pereonites, pleonites, and pleotelson, dorsal view. 3: Xanthosia sakoi new species, WMNH-Ge-1140320064 (holotype), carapace, dorsal view. 4, 5: Eomunidopsis kinokunica new species, WMNH-Ge-1140320058 (holotype). 4: carapace, dorsal view. 5: plaster cast of external mould, dorsal view. 6 - 9: Eryma nippon new species, WMNH-Ge-1140320056 (holotype). 6: Carapace and $1^{\text {st }}$ cheliped, lateral view. 7: Carapace, dorsal view. 8: Carapace, lateral view. 9: 1st cheliped, mesial view. 10 - 13: Hoploparia natsumiae new species, WMNH-Ge-1140320065 (holotype). 10: Left $1^{\text {st }}$ cheliped, mesial view. 11: Carapace, dorsal view. 12: Abdomen, lateral view. 13: Lateral view of carapace and dorsal view of abdomen. $1-3,6-13$, bar equal to $10 \mathrm{~mm} ; 4,5$, bar equal to $5 \mathrm{~mm}$. 
shallow dorsally, joining branchiocardiac groove. Inferior groove shallow. Carapace with scabrous ornamentation. Region between cervical and postcervical grooves coarsely scabrous. Intercalated plate narrow, longitudinally ridged; median suture following posterior end of intercalated plate, extending to posterior margin. Gastric region coarsely tuberculate; subdorsal carinae coarsely tuberculate.

Etymology. The new species is named for its occurrence in Nippon.

Description. Eryma with moderate sized body. Carapace width about $65 \%$ carapace length, height about $50 \%$ its length; surface with scabrous ornamentation. Rostrum poorly preserved, short, gently downturned, dorsoventrally flattened, with rimmed lateral margins; rostrum spines not preserved. Orbit concave. Supraorbital spine small. Antennal spine weakly developed, small, directed anterolaterally. Gastro-orbital groove very weak, inconspicuous, originating from median portion of cervical groove, becoming shallower toward anterior margin, terminating at about mid-length of gastric region. Antennal groove deep, arcuate ventrally, paralleling anterior margin laterally, extending dorsally to level of supraorbital spine. Cervical groove deep, sinuous, extending ventrally to join antennal groove. Prominence omega well defined, triangular, swollen. Prominence chi well defined, subrectangular, inflated. Hepatic groove deep, strongly sinuous, joining cervical and branchiocardiac grooves. Postcervical groove deep, but shallow dorsally, obliquely extending ventrally, to join branchiocardiac groove. Branchiocardiac groove shallow, slightly sinuous, extending anteroventrally to join shallow, concave forward inferior groove. Postmarginal groove weakly developed. Lateral margins rimmed. Region between cervical and postcervical grooves coarsely scabrous. Intercalated plate narrow, longitudinally ridged, extending from mid-point of rostrum to posterior one-third of gastric region; median suture posterior to intercalated plate, extending to posterior margin. Gastric region coarsely tuberculate; subdorsal carinae coarsely tuberculate, present on each side of intercalated plate.

Right $1^{\text {st }}$ cheliped poorly preserved. Merus about 3/5 longer than high with finely tuberculated dorsal and ventral margins. Carpus about 3/4 merus length; lateral margin finely tuberculate. Palm about 3/5 longer than high, about equal to merus length; margins and surfaces finely tuberculated. Dactylus broken and fixed finger not preserved.

Remarks. Eryma nippon new species is closely related with Eryma glaessneri (Van Straelen, 1936) from the Hauterivian of France, but differs by the presence of a weak branchiocardiac groove and the absence of post antennal spines. Kato et al. (2007) reported the cheliped identified with Erymidae gen. et sp. indet. from the Tithonian Somanakamura Group of Fukushima Prefecture, Japan. This species differs from E. nippon by having a punctuated surface.

Eryma has a geologic record ranging from the Early Jurassic to the Late Cretaceous and has a rich Jurassic record from Europe, North America, and Madagascar (Glaessner, 1969). The previously known Cretaceous records of Eryma are from France, Germany, England, Argentina, and Lebanon (Aguirre-Urreta, 1989). Among these, Eryma cretacea Roger, 1946, from the Cenomanian of Lebanon lacks the diagnostic characters of Eryma, absence of postcervical, branchiocardiac, hepatic, and inferior grooves, the prominence chi, and the intercalated plate. Therefore, Eryma cretacea might be referred to some other astacidean genus; however, detailed examination of type and additional material will be necessary to confirm the generic placement of this species, which is beyond the scope of this study.

Eryma nippon represents the first Cretaceous record of the genus from the North Pacific realm and the youngest occurrence of the genus.

Material examined. WMNH-Ge-1140320056 (holotype) from Loc. 2 collected by Y. Sako.

\author{
Superfamily Nephropoidea Dana, 1852a \\ Family Nephropidae Dana, 1852a \\ Subfamily Homarinae Huxley, 1879
}

\section{Genus Hoploparia McCoy, 1849}

Type species. Astacus longimanus Sowerby, 1826, by subsequent designation of Rathbun (1926).

\section{Hoploparia natsumiae new species}

Figures $2.11-2.13$

Diagnosis. Moderate-sized Hoploparia. Carapace with well defined cervical and postcervical grooves; antennal region with antennal ridge bearing small, forwardly directed spines; dorsomedian line weakly developed; supraorbital and subdorsal carinae weak, granular; regions between cervical and postcervical grooves coarsely granulated; median carina and lateral carinae finely granulate; sparsely granulated ridge present on branchial region behind postcervical groove, nearly parallel to postcervical groove. Propodus of $1^{\text {st }}$ cheliped slender, elongate; mesial surface and dorsal and ventral margins of propodus and dactylus smooth; both fingers slender, elongate, about 1.5 times palm length.

Etymology. The specific name is derived from the surname of N. Kumagai, who collected the type specimen.

Description. Hoploparia with moderate-sized body. Carapace about twice as long as high, surface with irregular, scabrous ornamentation. Rostrum not preserved. Orbit 
small, rounded. Postcervical groove well defined, deep, broad, obliquely extending ventrally, becoming shallower at junction with hepatic groove. Intercervical groove shallow, extending anteroventrally to, but not joining cervical groove. Second intercervical groove broad, shallow, extending to cervical groove. Hepatic groove shallow, curving to join antennal and cervical grooves. Cervical groove well defined, deep, slightly arcuate, parallel to postcervical groove, extending ventrally to join antennal groove. Antennal groove weakly arcuate, well defined over prominence omega. Prominence omega well defined, triangular. Gastro-orbital groove shallow, extending to near upper part of cervical groove. Antennal region with antennal ridge bearing small, forwardly directed spines; first antennal spine not preserved. Two postorbital spines present, small, longitudinally arranged. Dorsomedian line present, but inconspicuous. Supraorbital carinae granular, tapering distally, terminating at about anterior one-fourth of carapace length. Subdorsal carinae weak, finely granulate, tapering distally, not reaching posterior end of supradorsal carinae. Regions between cervical and postcervical grooves coarsely granulated. Median carina and lateral carinae finely granulate. Sparsely granulated ridge present on branchial region behind postcervical groove, nearly parallel to postcervical groove, extending from near junction with intercervical groove to lateral carina. Posterior margin sinuous.

Abdominal somites 1-4 poorly preserved; surfaces smooth. Pleura well developed, but detailed characters unknown.

Propodus of left $1^{\text {st }}$ cheliped slender, elongate, cylindrical, about 1.8 times length of carapace excluding rostrum. Mesial surface and dorsal and ventral margins of chela smooth. Palm height about 30 percent its length. Both fingers slender, elongate, about 1.5 times palm length.

Remarks. Hoploparia natsumiae new species possesses carapace characters most like those of Hoploparia intermedia Secretan, 1964, from the Albian of Madagascar, but differs in having the smooth mesial surface and dorsal and ventral margins of the $1^{\text {st }}$ cheliped. Hoploparia from Japan comprises three species, H. kamuy Karasawa and Hayakawa, 2000, from the Turonian-Santonian Upper Yezo Group, H. kamimurai Kato and Karasawa, 2006, from the Barremian Ishido Formation, and H. miyamotoi Karasawa, 1998, from the Maastrichtian Izumi Group. The present species is readily distinguished from these species because it has well developed carapace grooves and granulated supraorbital, subdorsal, median, and lateral carinae. Hoploparia natsumiae represents the second record of the genus from the Barremian of Japan.

Material examined. WMNH-Ge-1140320065 (holotype) from Loc. 2 collected by N. Kumagai.
Infraorder Anomala Boas, 1880

Superfamily Galatheoidea Samouelle, 1819

Family Galatheidae Samouelle, 1819

\section{Genus Eomunidopsis Via Boada, 1981}

Type species. Galathea navarrensis Van Straelen, 1940, by original designation of Via Boada (1981).

\section{Eomunidopsis kinokunica new species} Figures 2.4, 2.5

Diagnosis. Small-sized Eomunidopsis. Carapace excluding rostrum, subquadrate, slightly longer than wide, widest at mid-length. Rostrum triangular; lateral margins smooth, very weakly concave, rimmed; dorsal surface smooth with median ridge. Outer orbital angle not produced. Lateral margin gently convex without spines. Gastric, cardiac, hepatic, intestinal, and branchial regions ornamented with transverse and/or oblique ridges. Cervical groove deep, well defined. Postcervical groove moderately defined.

Etymology. The trivial name is derived from "Kinokuni", meaning Wakayama in an ancient age.

Description. Small-sized carapace for Eomunidopsis. Carapace excluding rostrum, subquadrate in outline, slightly longer than wide, widest at mid-length. Rostrum triangular, slightly downturned, about as long as wide, occupying about $43 \%$ carapace width at the base; lateral margin smooth, very weakly concave, rimmed. Orbital margin slightly concave. Outer orbital angle not produced. Lateral margin gently convex without spines. Posterior margin weakly concave. Dorsal surface moderately vaulted longitudinally. Dorsal surface of rostrum smooth, weakly concave longitudinally, with longitudinal ridge. Gastric regions inflated; epigastric regions interrupted medially, ornamented with 2 oblique ridges; protogastric and mesogastric regions confluent; anterior half with 3 transverse ridges; posterior half ornamented with 2 anterior transverse ridges, followed by sinuous ridge and posteriormost transverse ridge. Cervical groove deep, well defined. Anterior branchial regions ornamented with short, oblique ridges anteriorly. Postcervical groove moderately defined. Cardiac region poorly defined with gently curved anteriormost ridges and 4 transverse ridges. Posterior branchial regions ornamented with slightly oblique ridges. Intestinal region covered with 2 transverse ridges, extending to lateral margins across posterior branchial regions.

Remarks. The present new species has close affinity with Eomunidopsis meerssensis Collins et al., 1995, from the Maastrichtian of The Netherlands, but differs by having a wide base of the rostrum and gently convex lateral margins. This species resembles Eomunidopsis navarrensis (Van 
Straelen, 1940) from the Cenomanian of Spain, but differs by having a smooth dorsal surface of the rostrum and lacking granules and tubercles on ridges of the dorsal regions. The lateral margins in Eomunidopsis navarrensis are divergent posteriorly, but the species has gently arched lateral margins and is widest at the mid-length of the carapace. A wide rostrum and lateral margins without spines easily distinguish the present species from Eomunidopsis kojimai Karasawa and Hayakawa, 2000, the sole species hitherto known from the North Pacific regions.

Eomunidopsis kojimai has been recorded from the Santonian of Hokkaido. The discovery of the present species extends the geologic range for Eomunidopsis from the North Pacific rim back to the Barremian.

Material examined. WMNH-Ge-1140320058 (holotype) from Loc. 2 collected by M. Ohara.

Infraorder Brachyura Latreille, 1802 Section incertae sedis

Superfamily Etyoidea Guinot and Tavares, 2001, new rank

Included family. Etyidae Guinot and Tavares, 2001.

Diagnosis. as for family.

Family Etyidae Guinot and Tavares, 2001.

Type genus. Etyus Leach in Mantell, 1822.

Included genera. Etyus Leach in Mantell, 1822; Etyxanthosia Fraaije et al., 2008 in press; Feldmannia Guinot and Tavares, 2001; Guinotosia Beschin et al., 2007; Sharania Collins and Saward, 2006; Xanthosia Bell, 1863.

Geologic range. Early Cretaceous (Barremian)Eocene.

Diagnosis. Cephalothorax transversely oblong, much wider than long, dorsally flattened, branchial region elongated. Dorsal surface markedly areolated. Fronto-orbital margin wide. Front not projecting, straight to bilobed. Lateral margin distinct. Anterolateral margin convex with teeth, longer than posterolateral, both well delimited. Posterior margin narrow, more or less concave. Orbit large, deep. Urinal tubercles well developed. Epistome triangular. Buccal cavern quadrangular. Third maxillipeds operculiform, palp well developed. Cheliped elongated, merus long, stout fingers longer than palm. Anterior pair of legs long. Last two pairs subdorsal. Sternites 6-8 or 7-8, or only 8 subperpendicular to preceding sternites (upturned). Spermathecal openings at end of suture 7/8. Abdomen covering whole sternum in female. Sternite 4 large, visible beyond and laterally to telson in male. Abdomen fixed laterally by coxae of 1-2 anterior pairs of pereiopods. Uropods absent (from Števčić, 2005).

Remarks. Guinot and Tavares (2001) originally placed the Etyidae Guinot and Tavares, 2001, together with the Dakoticancridae Rathbun, 1917, Phyllotymolinidae Tavares, 1998, Cymonomidae Bouvier, 1897, Cyclodorippidae Ortmann, 1892, and Raninoidea de Haan, 1841, within the podotreme subsection Archaeobrachyura Guinot, 1977, based upon the presence of a pair of spermathecae at the end of the thoracic sternal suture between 7 and 8 and the absence of uropod of the abdomen. At that time, Guinot and Tavares (2001) did not place it within a known superfamily. After their work, Števčić (2005) placed the Etyidae within the superfamily Cyclodorippoidea Ortmann, 1892, without discussion. However, the Etyidae differs from the Cyclodorippidae, Cymonomidae, and Phyllotymolinidae in several important characters. The carapace is much wider than long and transversely hexagonal to ovate in outline, whereas in the Cyclodorippidae, Cymonomidae, and Phyllotymolinidae it is longer than wide or slightly wider than long, and usually ovate to circular in outline. The meri of maxillipeds 3 are subrectangular in outline, while the Cyclodorippidae, Cymonomidae, and Phyllotymolinidae have the elongated meri of maxilliped 3, which is sometimes visible dorsally. Based upon these differences, the Etyidae is herein elevated to superfamily status.

Although the Etyidae has been placed within the Podotremata, the systematic position of it has been uncertain. Recent phylogenetic works suggested that the Podotremata is not monophyletic and paraphyletic, based upon the molecular analysis (Ahyong and O'Meally, 2004; Ahyong et al., 2007) and the morphology-based cladistic analysis (Brösing et al., 2007). Ahyong et al. (2007) proposed three sections, Dromiacea de Haan, 1833, Raninoida de Haan, 1841, and Cyclodorippoida Ortmann, 1892 , for the podotreme group. The Raninoida with the Raninoidea is the sister to the Cyclodorippoida with the Cyclodorippoidea + Eubrachyura (Ahyong et al., 2007); therefore, the Archaeobrachyura sensu Guinot and Tavares (2001) is also paraphyletic. More morphology-based cladistic analysis within the "podotreme" families, including extant and extinct taxa, will be necessary to confirm the phylogenetic position of the Etyidae.

\section{Genus Xanthosia Bell, 1863}

Type species. Podophthalmus buchii Reuss, $1845=$ Xanthosia gibbosa Bell, 1863, by subsequent designation of Glaessner (1929).

Included species. $X$. buchii (Reuss, 1845); X. buteonis Wright and Collins, 1972; X. delicata Fraaye, 1996; $X$. elegans Roberts, 1962; X. granulosa (McCoy, 1854); X. 
gracilis Jakobsen and Collins, 1997; X. jacksoni Wright and Collins, 1972; X. occidentalis Bishop, 1991; X. robertsi Secretan, 1982; X. sakoi new species; X. semiornata Jagt et al., 1991; X. similis (Bell, 1863); X. spinosa Bishop, 1991; X. socialis van Bakel, Fraaije, and Jagt, 2005; $X$. zoquiapensis Fraaije et al., 2006.

Remarks. The genus Xanthosia is recognized as a heterogeneous group (Guinot and Tavares, 2001; Fraaije et al., 2008; Schweitzer per. com.); therefore, Guinot and Tavares (2001) erected a new genus Feldmannia for $X$. wintoni Rathbun, 1935, and moved Xanthosia arcuata Secretan, 1964, to a new heterotreme genus Secretanella. Most recently, Fraaije et al. (2008) proposed a new genus Etyxanthosia for Xanthosia aspera Rathbun, 1935, X. fossa Wright and Collins, 1972, X. pawpawensis Schweitzer Hopkins et al., 1999, and X. reidi Schweitzer Hopkins et al., 1999. However, a further generic level reconsideration of remaining species of Xanthosia is needed (Guinot and Tavares, 2001; Karasawa and Schweitzer, 2006; Schweitzer per. com.).

\section{Xanthosia sakoi new species}

Figure 2.3

Diagnosis. Moderate-sized Xanthosia. Carapace hexagonal, wider than long, widest at mid-length. Frontoorbital margin wide. Front bearing 2 rounded lobes, weakly separated from small inner orbital angle. Orbit small. Upper orbital margin narrow with 2 shallow, upper orbital fissures. Anterolateral margin with 4 lobes; $1^{\text {st }}$ lobe (=outer orbital angle) smallest, acutely triangular; $2^{\text {nd }}-4^{\text {th }}$ lobes broadly triangular; $3^{\text {rd }}$ and $4^{\text {th }}$ lobes larger than $2^{\text {nd }}$ lobe. Posterolateral margin slightly shorter than anterolateral margin, slightly sinuous. Posterior margin slightly concave, narrow. Dorsal surface gently convex, covered with fine granules. Protogastric regions wide, strongly tumid. Mesogastric region flattened posteriorly. Hepatic regions strongly tumid, weakly separated from protogastric regions by shallow, wide depression. Cervical groove sinuous, medially interrupted. Cardiac region pentagonal, flattened. Branchiocardiac grooves shallow. Epibranchial regions slightly swollen. Meso- and metabranchial regions undifferentiated.

Etymology. From Y. Sako who collected the type specimen.

Description. Moderate-sized carapace for Xanthosia. Carapace hexagonal in outline, length about $66 \%$ maximum carapace width, widest at mid-length. Fronto-orbital margin about $65 \%$ carapace width. Front bilobed, composed of 2 rounded lobes, medially interrupted by deep V-shaped notch, separated from broadly triangular inner orbital angle by weak $\mathrm{V}$-shaped groove. Upper orbital margin narrow, concave, with 2 shallow, upper orbital fissures. Anterolateral margin convex with 4 lobes; $1^{\text {st }}$ lobe (=outer orbital angle) smallest, acutely triangular, directed anteriorly; $2^{\text {nd }}$ and $3^{\text {rd }}$ lobes broadly triangular, directed anterolaterally; $3^{\text {rd }}$ and $4^{\text {th }}$ lobes larger than $2^{\text {nd }}$ lobe; $4^{\text {th }}$ lobe broadly triangular, directed laterally. Posterolateral margin slightly shorter than anterolateral margin, slightly sinuous. Posterior margin slightly concave, about $24 \%$ carapace width. Dorsal surface gently convex transversely and longitudinally. Surface covered with fine granules. Protogastric regions wide, strongly tumid. Mesogastric region triangular posteriorly, flattened, separated from protogastric regions by shallow, narrow groove, with narrow anterior mesogastric process. Hepatic regions strongly tumid, weakly separated from protogastric regions by shallow, wide depression. Cervical groove sinuous; lateral elements gently concave, wide, shallow; axial element moderately concave, narrow, shallow, medially interrupted. Urogastric region narrow, much wider than long, separated from cardiac region by shallow, narrow furrow. Cardiac region pentagonal, slightly wider than long, flattened. Intestinal region flattened. Branchiocardiac grooves shallow, wide. Epibranchial regions slightly vaulted. Meso- and metabranchial regions undifferentiated.

Remarks. The present species is closely related to Xanthosia buteonis Wright and Collins, 1972, from the Lower Albian of England, but differs in having a narrow orbit, two rounded frontal lobes, shallow cervical grooves, a wide intestinal region. Xanthosia sakoi has a broadly triangular last anterolateral tooth, while $X$. buteonis has a bifid last anterolateral tooth. Additionally, the carapace of Xanthosia sakoi is much wider than that of $X$. buteonis.

The previously known members of Xanthosia have been recorded from Europe, Madagascar, and Gulf Coastal Plain, Atlantic Coastal Plain, and Western Interior of North America, ranging from the Early Cretaceous (Aptian) to the Danian (Schweitzer Hopkins et al., 1999; Guinot and Tavares, 2001; van Bakel et al., 2005). The discovery of Xanthosia from Japan extends the known geologic range for this genus back to the Early Cretaceous (Barremian) and greatly expands the geographic range to the west side of the North Pacific realm.

Material examined. WMNH-Ge-1140320064 (holotype) from Loc. 3 collected by Y. Sako.

Order Isopoda Latreille, 1817

Suborder Cymothoida Wägele, 1989

Superfamily Cirolanoidea Dana, 1852b

Family Cirolanidae Dana, 1852b

\section{Genus Palaega Woodward, 1870 sensu lato}

Type species. Palaega carteri Woodward, 1870, by monotypy. 
Remarks. Feldmann and Rust (2006) listed 26 species referred to as Palaega. After that, Polz et al. (2006) described two new species, Palaega willmandingensis and Palaega nusplingensis, from the Upper Jurassic of Germany. Among these, Palaega undecimspinosa Karasawa et al., 1992, from the Miocene of Japan is excluded here because Karasawa et al. (1995) moved it to Bathynomus A. Milne Edwards, 1879. Palaega has a wide geologic record extending from the Triassic to Pliocene and has been reported from Europe, Africa, America, and New Zealand. Recognition of Palaega yamadai new species greatly expands the geographic range for the genus to the west side of the North Pacific region.

\section{Palaega yamadai new species}

Figures 2.1, 2.2

Diagnosis. Small-sized Palaega. Posterior half of all pereonites and pleonites ornamented with fine, longitudinal striations. Pleotelson ovate, longer than wide, narrowing posteriorly, widest at suture with pleonite 5 ; posterior margin finely dentate.

Etymology. From S. Yamada who collected the type specimen.

Description. Small-sized for genus. Pereonites decreasing in length posteriorly with posteriorly curved pleurae; posterior half of all pereonites ornamented with fine, longitudinal striations. Pleonites 1-5 with posteriorly directed pleurae; posterior half of all pleonites with fine, longitudinal striations. Pleotelson ovate, longer than wide, narrowing posteriorly, widest at suture with pleonite 5; dorsal surface with well defined median carina; posterior margin poorly preserved, convex, finely dentate.

Remarks. Palaega yamadai new species resembles Palaega williamsonensis Rathbun, 1935, from the Upper Cretaceous of Texas by having a finely dentate posterior margin of the pleotelson. However, it differs from $P$. williamsonensis by the presence of fine, longitudinal striations on all pereonites and pleonites. The present species represents the first occurrence in the Early Cretaceous of Japan.

Material examined. WMNH-Ge-1140320049 (holotype) and WMNH-Ge-1140320050 (paratype) from Loc. 1 collected by S. Yamada.

\section{Acknowledgements}

We thank N. Kumagai (Hannan, Osaka), Y. Sako (Kushimoto, Wakayama), and S. Yamada (Kimino, Wakayama) for offering us specimens, A. Nakase (Yuasa,
Wakayama) for allowing us to collect fossils in his quarry, and F. J. Vega (Universidad Nacional Autónoma de México) for assisting in our manuscript. I am grateful for the reviews by R. M. Feldmann (Kent State University, U.S.A.), R. H. B. Fraaije (Oertijdmuseum de Groene Poort, The Netherlands), and T. Nyborg (Loma Linda University, U.S.A.).

\section{References}

Aguirre-Urreta, M.B., 1989, The Cretaceous decapod Crustacea of Argentina and the Antarctic Peninsula: Palaeontology, 32, 499552.

Ahyong, S.T., O'Meally, D., 2004, Phylogeny of the Decapoda Reptantia: resolution using three molecular loci and morphology: Raffles Bulletin of Zoology, 52, 673-693.

Ahyong, S.T., Lai, J.C.Y., Sharkey, D., Colgan, D.J., Ng, P.K.L., 2007, Phylogenetics of the brachyuran crabs (Crustacea: Decapoda): the status of Podotremata based on small subunit nuclear ribosomal RNA: Molecular Phylogenetics and Evolution, 45, 576-586.

Bakel, B.W.M. van, Fraaije R.H.B., Jagt, J.W.M., 2005, A new Early Campanian species of Xanthosia (Decapoda, Brachyura) from northwestern Germany: Crustaceana, 78, 285-295.

Beschin, C., Busulini, A., De Angeli, A., Tessier, G., 2007, I Decapodi dell'Eocene inferiore di Contrada Gecchelina (Vicenza - Italia settentrionale) (Anomura e Brachiura). Museo di Archeologia e Scienze Naturali "G. Zannato", Montecchio Maggiore (Vicenza), 9-76.

Bell, T., 1863, A Monograph of the fossil malacostracous Crustacea of Great Britain, Pt. II, Crustacea of the Gault and Greensand: Palaeontographical Society Monographs, London, 40 p., 11 pls.

Bishop, G.A., 1991, Xanthosia occidentalis Bishop, 1985, and Xanthosia spinosa new species, two late Cretaceous crabs from the Pierre Shale of the western Interior: Journal of Crustacean Biology, 11, 305-314.

Boas, J.E.V., 1880, Studier over Decapodernes Slaegtskabsforhold: Kongelige Danske Videnskabernes Selskabs Skrifter, Naturvidenskabelig og Mathematisk Affeling, series 5, 6, 25-210.

Bouvier, E.-L., 1897, Sur la classification, les origines et la distribution des Crabes de la famille des Dorippidés: Bulletin de la Société philomatique, Paris, series 8, 9, 54-70.

Brösing, A., Richter, S., Scholz, G., 2007, Phylogenetic analysis of the Brachyura (Crustacea, Decapoda) based on characters of the foregut with establishment of a new taxon: Journal of Zoological Systematics and Evolutionary Research, 45, 20-32.

Collins, J.S.H., Saward, J., 2006, Three new genera and species of crabs from the Lower Eocene of London Clay of Essex, England: Bulletin of the Mizunami Fossil Museum, 33, 67-76.

Collins, J.S.H., Fraaye, R.H.B., Jagt, J.W.M., 1995, Late Cretaceous anomurans and brachyurans from the Maastrichtian type area: Acta Palaeontologica Polonica, 40, 165-210.

Dana, J.D., 1852a, Crustacea: United States Exploring Expedition during the Years 1838, 1839, 1840, 1841, 1842 Under the Command of Charles Wilkes, U.S.N., 13, 1620 p.

Dana, J.D., 1852b, On the classification of the Crustacea Choristopoda or Tetradecapoda: American Journal of Science and Arts, series 2, $14,297-316$

De Haan, W., 1833-1850, Crustacea. In, Siebold, P. F. von, Fauna Japonica sive descriptio animalium, quae in Itinere per Japoniam, Jussu et auspiciis superiorum, qui Summun in India Batava Imperium tenent, suscepto, annis 1823-1830 collegit, notis, observationibus et adumbrationibus illustravit; Ludguni-Batavorum, i-xvii + i-xxxi $+\mathrm{ix}-\mathrm{xvi}+1-243$, pls. A-J + L-Q + 1-55

Feldmann, R.M., Rust, S., 2006, Palaega kakatahi n. sp.: the first record of a marine isopod from the Pliocene of New Zealand: New Zealand Journal of Geology and Geophysics, 49, 411-415.

Fraaije, R.H.B., Van Bakel, W.M., Jagt, J.W.M., Artal, P., 2008 in press, 
New decapod crustaceans (Anomura, Brachyura) from Middle Cretaceous reefal deposits at Monte Orobe (Navarra, northern Spain), and comments on related type-Maastrichtian material: Bulletin de l'Institut royal des Sciences naturelles de Belgique, Sciences de la Terre, 78

Fraaije, R.H.B., Vega, F.J., van Bakel, B.M., Garibay-Romero, L.M., 2006, Late Cretaceous dwarf decapods from Guerrero, southern Mexico and their migration patterns: Contributions to Zoology, $75,121-132$

Fraaye, R.H.B., 1996, Late Cretaceous swimming crabs: radiation, migration, competition, and extinction: Acta Geologica Polonica, 46, 269-278.

Glaessner, M.F., 1929, Crustacea Decapoda, Part 41, p. 1-141: In J.F. Pompeckj (ed.), Fossilium Catalogus I: Animalia. W. Jünk, Berlin.

Glaessner, M.F., 1969, Decapoda, p. R399-R651: In R.C. Moore (ed.), Treatise on Invertebrate Paleontology, Part R, Arthropoda 4. Vol. 2. Geological Society of America and University of Kansas Press.

Guinot, D., 1977, Propositions pour une nouvelle classification des Crustacés Décapodes Brachyoures : Comptes Rendus hebdomadaires des Séances de l'Académie des Sciences, Paris, Série D, 285: 1049-1052.

Guinot, D., Tavares, M., 2001, Une nouvelle famille de Crabes du Cretacé et la notion de Podotremata Guinot, 1977 (Crustacea, Decapoda, Brachyura): Zoosystema, 23, 507-546.

Huxley, T.H., 1879 [1878], On the classification and the distribution of the crayfishes: Proceedings of the Scientific Meetings of the Zoological Society of London, 1878, 752-788.

Jakobsen, S.L., Collins, J.S.H., 1997, New Middle Danian species of anomuran and brachyuran crabs from Fakse, Denmark: Bulletin of the Geological Society of Denmark, 44, 89-100.

Jagt, J.W.M., Collins, J.S.H., Fraaye, R.H.B., 1991, Anew late Maastrichtian xanthid crab from southern Limburg (the Netherlands): Cretaceous Research, 12, 553-560.

Karasawa, H., 1998, Two new species of Decapoda (Crustacea) from the Upper Cretaceous Izumi Group, Japan: Paleontological Research, $2,217-223$

Karasawa, H., 2000, Discovery of Early Cretaceous (Barremian) decapod Crustacea from the Arida Formation of Wakayama Prefecture, Japan: Paleontological Research, 4, 235-238.

Karasawa, H., Hayakawa, H., 2000, Additions to Cretaceous decapod crustaceans from Hokkaido, Japan-Part 1. Nephropidae, Micheleidae and Galatheidae: Paleontological Research, 4, 139145 .

Karasawa, H., Schweitzer, C.E., 2006, A new classification of the Xanthoidea sensu lato (Crustacea: Decapoda: Brachyura) based on phylogenetic analysis and traditional systematics and evaluation of all fossil Xanthoidea sensu lato. Contributions to Zoology, 75, 23-73.

Karasawa, H., Kato, H., Terabe, K., 2006, A new member of the family Prosopidae (Crustacea: Decapoda: Brachyura) from the Lower Cretaceous of Japan: Revista Mexicana de Ciencias Geológicas, $23,344-349$.

Karasawa H., Nobuhara T., Matsuoka, K., 1992, Fossil and living species of the giant isopod genus Palaega Woodward, 1870 of Japan: Science Reports of the Toyohashi Museum of Natural History, 2, 1-12.

Karasawa. H., Suzuki, A., Kato, H., 1995, Bathynomus undecimspinosus (Karasawa, Nobuhara \& Matsuoka, 1992) (Crustacea, Isopoda) from the Miocene Hidarimatagawa Formation of southwestern Hokkaido, Japan: Bulletin of the Mizunami Fossil Museum, 22, 121-125.

Kato, H., Karasawa, H., 2006, New nephropid and glypheid lobsters from the Mesozoic of Japan: Revista Mexicana de Ciencias Geológicas, 23, 338-343.

Kato, H., Takahashi, T., Taira, M., 2007, Decapod crustaceans from the upper Jurassic of Somanakayama Group, northeast Japan: first record of the Jurassic crab from the circum Pacific region: Abstracts with Programs, The 156th Regular Meeting, The Palaeontological Society of Japan, Tokushima, Japan, 26.

Kato, H., Karasawa, H., Terabe, K., Sato, K., Takakuwa, Y., Kamimura, H., 2006, Decapod crustaceans from the lower Cretaceous of Sanchu region: Abstracts with Programs, The 2006 Annual Meeting, The Palaeontological Society of Japan, Matsue, Japan, 64.

Komatsu, T., 1999, Depositional environments and bivalve fossil assemblages of the Lower Cretaceous Arida Formation, southwest Japan: The Journal of the Geological Society of Japan, 105, 643650.

Latreille, P.A., 1802-1803, Histoire naturelle, générale et particulière, des Crustacés et des Insectes, volume 3: F. Dufart, Paris, 467 p.

Latreille, P.A., 1817, Nouveau dictionnaire d'histoire naturelle, appliquée aux arts, à l'agriculture, à l'economie rurale et domestique, à la médecine, etc. volume 10: Déterville, Paris, $404 \mathrm{p}$.

Leach, W.E., 1815, A tabular view of the external characters of four classes of animals, which Linné arranged under Insecta, with the distribution of the genera composing three of these classes into orders, and description of several new genera and species: Transactions of the Linnean Society of London, 11, 306-400.

Mantell, G.A., 1822, The Fossils of the South Downs; or Illustrations of the Geology of Sussex: Lupton Relfe, London, 327 p., 42 pls.

Matsukawa, M., Obata, I., 1993, The ammonites Crioceratites and Shasticrioceras from the Barremian of southwest Japan: Palaeontology, 36, 249-266.

Matsumoto, T., 1947, On some interesting ammonites from Paleocretaceous of the Yuasa district, southwest Japan: Science Reports of Kyushu University, Geology Series, 2, 13-18.

McCoy, F., 1849, On the classification of some British fossil Crustacea with notices of new forms in the University Collection at Cambridge: Annals and Magazine of Natural History, series 2, 4, 161-179, 330-335.

McCoy, F., 1854, On some new Cretaceous Crustacea: Annals and Magazine of Natural History, series 2, 14, 116-122.

Meyer, H. von, 1840, Neue Gattungen fossiler Krebse aus Gebilden vom bunten Sandstein bis in die Kreide: Zoological Museum, Stuttgart, $28 \mathrm{p} ., 4 \mathrm{pls}$.

Milne Edwards, A., 1879, Sur un isopode gigantesque des grandes profondeurs de la mer: Comptes Rendus de l'Académie des Sciences, Paris, 88, 21-23.

Obata, I., Ogawa, M., 1976, Ammonite biostratigraphy of the Cretaceous Arida Formation, Wakayama Prefecture: Bulletin of the National Science Museum, series C, 2, 93-110.

Ortmann, A., 1892, Die Abtheilungen Hippidea, Dromiidea und Oxystomata: Die Decapoden-Krebse des Strassburger Museums, mit besonderer Berücksichtigung der von Herrn Dr. Döderlein bei Japan und bei den Liu-Kiu-Inseln gesammelten und z.Z. im Strassburger Museum aufbewahrten Formen. V. Theil: Zoologische Jahrbücher, Abtheilung für Systematik, Geographie und Biologie der Thiere, $6,532-588$, pl. 26

Polz, H., Schweigert, G., Maisch, M.W., 2006, Two new species of Palaega (Isopoda: Cymothoida: Cirolanidae) from the Upper Jurassic of the Swabian Alb, South Germany: Stuttgarter Beiträge zur Naturkunde, Serie B (Geologie und Paläontologie), 362, 1-17.

Rathbun, M.J., 1917, New species of South Dakota Cretaceous crabs: Proceedings of the U.S. National Museum, 52, 385-391.

Rathbun, M.J., 1926, The fossil stalk-eyed Crustacea of the Pacific slope of North America: U. S. National Museum, Bulletin, 138, 155 p.

Rathbun, M.J., 1935, Fossil Crustacea of the Atlantic and Gulf Coastal Plain: Geological Society of America Special Paper, 2, viii + $1-160$.

Reuss, A., 1845-1846, Die Versteinerungen der Böhmischen KreideFormation: Schweizerbart, Stuttgart, iv +58 p. (1845); iv +148 p. (1846).

Roberts, H.B., 1962, The upper Cretaceous decapod crustaceans of New Jersey and Delaware, p. 163-191: In H. B. Richard (ed.), The Cretaceous Fossils of New Jersey, Paleontology series 61, Bureau of Geology and Topography Kemble Widner, State Geologist, Trenton.

Roger, J., 1946, Les invertébrés des couches poissons du Crétacé supérieur du Liban: Mémoires de la Société géologique de France, 23, 1-92.

Samouelle, G., 1819, The Entomologist's Useful Compendium, or an Introduction to the Knowledge of British Insects: London, $486 \mathrm{p}$. 
Schlotheim, E. F. von, 1822, Beiträge zur näheren Bestimmung der versteinerten und fossilen Krebsarten: Nachträge zur Petrefactenkunde, 2, 1-88, pls. 1-29.

Schweitzer Hopkins, C.E., Salva, W., Feldmann, R.M., 1999, Reevaluation of the genus Xanthosia Bell, 1863 (Decapoda: Brachyura: Xanthidae) and description of two new species from the Cretaceous of Texas: Journal of Paleontology, 73, 77-90.

Secretan, S., 1964, Les Crustacés décapodes du Jurassique supérieur et du Crétacé de Madagascar: Mémoires du Muséum National d'Histoire Naturelle, Nouvelle série, Série C, Sciences de la Terre, 14, 226 p., 20 pls.

Secretan, S., 1982, Xanthosia robertsi, Crustacé décapode du Crétacé de Madagascar: nouveau nom et nouvelles hypothèse sur son origine: Géobios, 15, 927-933.

Sowerby, J., 1826, Description of a new species of Astacus, found in a fossil state at Lyme Regis: Zoological Journal, 2, 493-494.

Števčić, Z., 2005., The reclassification of brachyuran crabs (Crustacea: Decapoda: Brachyura): Natura Croatica, 14, supplement 1, 1-159.

Tavares, M., 1998, Phyllotymolinidae, nouvelle famille de Brachyoures Podotremata (Crustacea, Decapoda): Zoosystema, 20, 109-122.

Van Straelen, V., 1924 [1925], Contribution à l'étude des crustacés décapodes de la période jurassique: Memoires d'Academie Royale de Belgique, Classe des Sciences, collected in number 4, series 2 , 7, 1-462, pls. 1-10.

Van Straelen, V., 1936, Crustacés décapodes nouveaux ou peu connus de l'époque Crétacique: Bulletin du Musée Royal d'Histoire Naturelle de Belgique, tome 15, 12, 1-49.
Van Straelen, V., 1940, Crustacés décapodes nouveaux du crétacique de la Navarre: Bulletin du Muée royal d'Histoire naturelle de Belgique, tome 16, 4, 1-5.

Via Boada, L., 1981, Les Crustacés décapodes du Cénomanien de Navarre (Espagne): Premier résultats de l'étude des Galatheidae: Géobios, 14, 247-251.

Wägele, J.-W., 1989, Evolution und phylogenetisches System der Isopoda. Stand der Forschung und neue Erkenntnisse: Zoologica, $140,1-262$.

Woodward, H., 1870, Contributions to British fossil Crustacea: Geological Magazine, 7, 493-497.

Wright, C.W., Collins, J.S.H., 1972. British Cretaceous Crabs: Palaeontographical Society Monographs, London, 126, 1-113.

Manuscript received: June 11, 2008

Corrected Manuscript received: July 8, 2008

Manuscript acepted: July 11, 2008 